\title{
Chrysothrix bergeri (Ascomycota: Arthoniales: Chrysothricaceae), a new lichen species from the southeastern United States, the Caribbean, and Bermuda
}

\author{
Scott LaGreca*
}

\author{
Article info \\ Received: 25 Apr. 2020 \\ Revision received: 14 Oct. 2020 \\ Accepted: 14 Oct. 2020 \\ Published: 29 Dec. 2020 \\ Associate Editor \\ Martin Kukwa
}

\begin{abstract}
A crustose lichen species new to science - previously characterized in the literature but unnamed - is formally described. This new species, Chrysothrix bergeri sp. nov., ranges from the southeastern United States southwards to the Caribbean islands (Bahamas and Cuba) and eastwards to Bermuda. It is most easily confused with C. xanthina, from which it differs in both chemistry and ascospore shape. Bilimbia aurata and Bilimbia stevensoni are both confirmed as synonyms of C. xanthina. A lectotype is selected for Bilimbia aurata. Solvent E is recommended for the chromatographic separation of leprapinic and pinastric acids - two lichen secondary products critical for diagnosing certain species of Chrysothrix, including C. bergeri.
\end{abstract}

Key words: Arthoniomycetes, leprapinic acid, Neotropics, pinastric acid, taxonomy

\section{Introduction}

Active revision of Bermuda's lichen flora over the past 12 years has resulted in multiple new species and combinations (Aptroot et al. 2008; Berger \& Aptroot 2008; Berger \& LaGreca 2014; Berger et al. 2016). While doing field work in the archipelago in 2004, Franz Berger collected an unknown species of Chrysothrix along the Bermuda Railway Trail in Southampton Parish. Additional field work, as well as herbarium work, produced other Bermudian specimens of this taxon. A review of the literature pointed towards a widespread, yet undescribed, species ('Chrysothrix sp.') discussed in detail by Harris and Ladd (2008) from the southeastern United States and Caribbean islands. The new species is distinguishable from similar species in these regions by its possession of smaller granules and/or it consistent production of calycin as its major secondary product. The present paper contributes further to our knowledge of the lichen diversity of both North America and the Neotropics with a formal description of this new species.

\section{Materials and methods}

Material from Bermuda was compared with all specimens of 'Chrysothrix sp.' cited in Harris and Ladd (2008) borrowed from KANU, NY and the private herbarium of

Department of Biological Sciences, 137 Biological Sciences Building, 130 Science Drive, Box 90338, Duke University, North Carolina 27708-0338, USA

* Corresponding author e-mail: scott.lagreca@duke.edu
Doug Ladd (hb. Ladd). In addition, comparable specimens of Chrysothrix from the southeastern United States, the Caribbean, and Bermuda from FH and US were hand-selected in-person, with fragments taken (with permission) for further examination. European specimens of C. candelaris from DUKE were also examined for comparison with North American species (NB: all BM, CUP and DUKE specimens cited herein were studied during the author's employment at those herbaria).

All specimens were examined with a Bausch \& Lomb StereoZoom 5 dissecting microscope. Granules were scraped from specimens and mounted dry as per Harris and Ladd (2008), then measured using an Olympus CX43 compound microscope. Hand-cut sections of ascomata were mounted in water, and then examined at $400 \times$ and $1000 \times$ magnification (the latter in oil immersion). The micrograph showing thallus morphology (Fig. 1) was taken using a Canon Rebel Xsi camera attached to a Leica MZ125 dissecting microscope.

Thin-layer chromatography (TLC) was performed on all specimens using pre-gelled silica plates and the following solvents: A, B', C and E (Culberson \& Ammann 1979; Culberson \& Johnson 1982; Elix \& Crook 1992). Four representative specimens (marked with an asterisk in the specimen list at the end) were sent to Jack Elix (CANB) for verification by TLC (solvent E only). Authentic samples of calycin, leprapinic acid, pinastric acid - and, on Jack's plates, isoleprapinic acid - were included on each plate as controls. 


\section{Results and discussion}

Chrysothrix bergeri LaGreca, sp. nov.

(Figs 1-2)

MycoBank MB 837767

Type: Cuba, Confianza Estate, 4 March 1922, Bro. Hioram 5771 (NY 00953971 - holotype!).

Description (adopted largely from Harris and Ladd 2008, with additions). Thallus crustose, leprose, corticolous or lignicolous, thin to moderately thick $(\sim 1 \mathrm{~mm})$, unstratified, bright yellow, granular, rhizohyphae absent; granules (15-)20-45(-60) $\mu \mathrm{m}$ across (averages 30-37.5 $\mu \mathrm{m}$ ); apothecia arthonioid, semi-immersed, yellow pruinose, $\sim 0.1-0.2 \mathrm{~mm}$ in diameter; asci more or less globose, 8-spored, $\sim 18 \times 25 \mu \mathrm{m}$; ascospores 3 -septate, with no medial constriction, sometimes pointed at one end, $\sim 9-15$ $\times 3-4 \mu \mathrm{m}$; pycnidia not observed.

Chemistry. $\mathrm{K}+/$ - reddish, $\mathrm{KC}+/$ - reddish, C-, PD-, UV-. Two chemotypes known: (1) calycin (major) plus pinastric acid (major) and leprapinic acid (minor) (15 specimens) and (2) calycin only (eight specimens).

Etymology. Named in honor of medical doctor Franz Berger (Kopfing, Austria), a prolific collector of neotropical lichens and lichenicolous fungi, and the first person to recognize this new taxon in Bermuda. Dr. Berger has contributed enormously to our understanding of not only Bermuda's lichens, but the lichens of many other North Atlantic island groups (the Azores, Canary Islands, and Madeira) as well.

Ecology and distribution. This species is known primarily from hardwood trees and shrubs - mostly Quercus spp. (Harris \& Ladd 2008), but also from others, e.g., Casuarina equisetifolia, Prunus caroliniana, and Suriana maritima. Two specimens were collected from dead Juniperus bermudiana wood (Berger 22365, DUKE and LaGreca 2510, BM); one from the bark of a live $J$. bermudiana (Hervey s.n., FH); two from dead Pinus bark (Ladd 14600, hb. Ladd; Harris 43313, NY); and one from Taxodium (Evans 88, FH). The species ranges from the southeastern United States, southwards to the Caribbean islands (Bahamas and Cuba), and eastwards to Bermuda (Fig. 3)

Remarks. The new species can be distinguished from all other Chrysothrix species in the areas that it occurs by its (a) small granule size; (b) ascospores with no medial constrictions, and sometimes with one pointed end; and (c) consistent production of calycin as its major secondary product, sometimes together with leprapinic acid (major) and pinastric acid (minor or trace).

In the Coastal Plain of the southeastern United States where most specimens have been collected - Chrysothrix bergeri can be most easily confused with $C$. xanthina (BM!, lectotype selected by Laundon 1981: 110), a common lichen also found on hardwood bark (Lendemer et al. 2016; Lendemer \& Noell 2018) that has granules the same size and color as $C$. bergeri. The two can be separated, however, by TLC. C. bergeri always produces calycin, whereas $C$. xanthina produces pinastric acid only. In addition, unlike $C$. xanthina, the ascospores of $C$. bergeri have no medial constrictions, and are sometimes pointed at one end (although these characters are of limited use, since $C$. bergeri is usually sterile). Chrysothrix xanthina was resurrected from synonymy with $C$. candelaris by Kalb (2001) by virtue of its smaller granules and different chemistry (calycin in C. candelaris s.str. versus pinastric acid in C. xanthina). Over the intervening 20 years, there has been disagreement on the size of the granules produced by C. candelaris s.str. According to Kalb (2001) and Fletcher and Purvis (2009), the granules of C. candelaris s.str. are large, ranging from $75-200 \mu \mathrm{m}$ and from

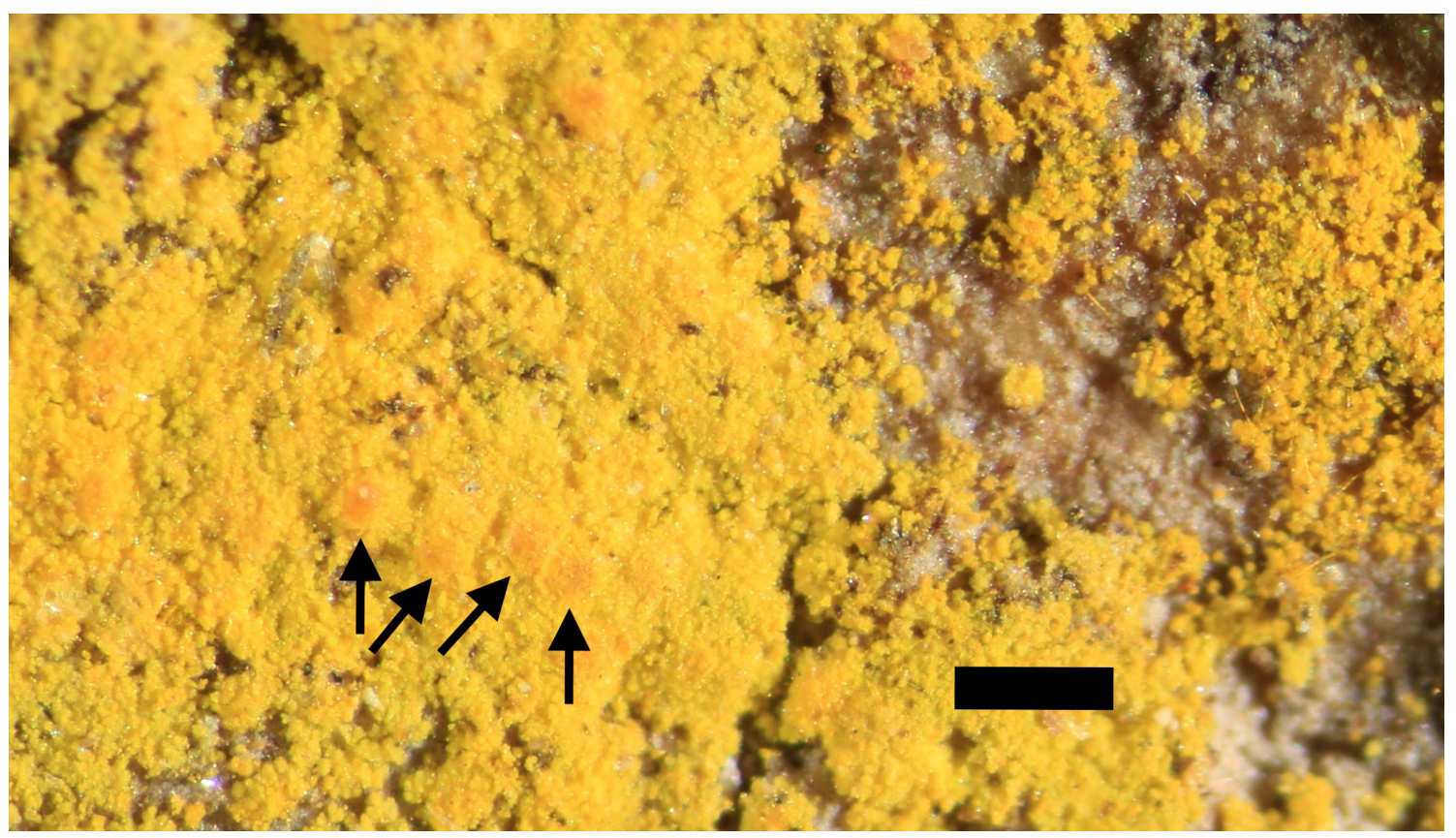

Figure 1. Thallus of Chrysothrix bergeri (Hioram 5771, NY - holotype). Apothecia are marked with arrows. Scale $=250 \mu \mathrm{m}$. 

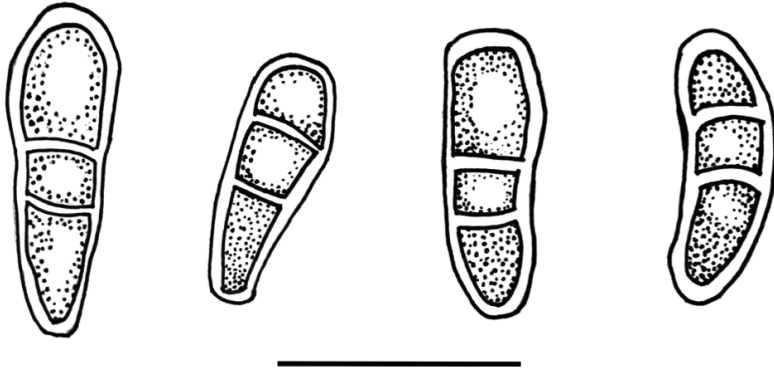

Figure 2. Ascospores of Chrysothrix bergeri (Hioram 5771, NY - holotype). Scale $=10 \mu \mathrm{m}$.

10-300 $\mu \mathrm{m}$, respectively; but Harris and Ladd (2008) and Olszewska et al. (2014) recorded granules between 50-75 $\mu \mathrm{m}$ and 20-50 $\mu \mathrm{m}$ (but most 30-40 $\mu \mathrm{m}$ ), respectively. Tønsberg (1992) reported even smaller granules for this species from Norway $[(6-) 12-25(-30) \mu \mathrm{m}]$. As Kukwa and Knudsen (2011) rightly point out, these discrepancies indicate that further study of material from throughout the geographic range of $C$. candelaris s.str. is needed to ascertain whether it is one morphologically and perhaps also chemically (see Olszewska et al. 2014) variable species occurring in Europe or a complex of poorly understood taxa. By contrast, the reported granule sizes for both $C$. xanthina and $C$. bergeri are more consistent, ranging between 20 and $50 \mu \mathrm{m}$ (e.g., Kalb 2001; Harris \& Ladd 2008; Kukwa \& Knudsen 2011). As Kukwa and Knudsen (2011) noted, the unusually large granule sizes $(20-80 \mu \mathrm{m})$ reported for Australian C. xanthina by Elix and Kantvilas (2007) were probably due to the measurement of granule aggregations, rather than true granules. Differences in reported granule sizes for both species could also be due to dry-mounting the granules (e.g., Harris \& Ladd 2008) vs. mounting in water (e.g., Kalb 2001; Olszewska et al. 2014). All of this suggests it is impossible to confidently key out all specimens of Chrysothrix based on granule size alone, however, any attempts to use this character should include careful measurement of the largest (single) granules.

TLC, on the other hand, reveals a major difference between Chrysothrix candelaris s.str. (sensu Kalb 2001) and $C$. xanthina. The former species always produces large amounts of calycin, sometimes with pinastric acid in minor or trace amounts, while the latter produces pinastric acid only (Kalb 2001). Like C. candelaris s.str., C. bergeri produces calycin as its major substance, but, as noted above, most specimens of $C$. bergeri can be differentiated from $C$. candelaris s.str. by their production of minor amounts of leprapinic acid.

In any case, Chrysothrix candelaris s.str. is a strictly European species (Kukwa \& Knudsen 2011; Olszewska et al. 2014) with modern workers agreeing that all North American specimens of ' $C$. candelaris' are referable to other species - mostly C. xanthina (Harris \& Ladd 2008; Kukwa \& Knudsen 2011), and to a lesser extent, C. bergeri (this paper). There is also some indication that $C$. xanthina and $C$. bergeri typically occur in warmer climes and more disturbed habitats than $C$. candelaris s.str. Interesting discussions of these ecological preferences (for C. candelaris s.str. vs. C. xanthina) are presented by both Kalb (2001) and Olszewska et al. (2014), but their observations require more rigorous verification.

Because of the numerous, complicated synonyms that exist for Chrysothrix candelaris (Laundon 1981), Harris and Ladd (2008) cautiously refrained from formally describing the taxon named here as $C$. bergeri. A literature search, however, revealed that the type specimens of all

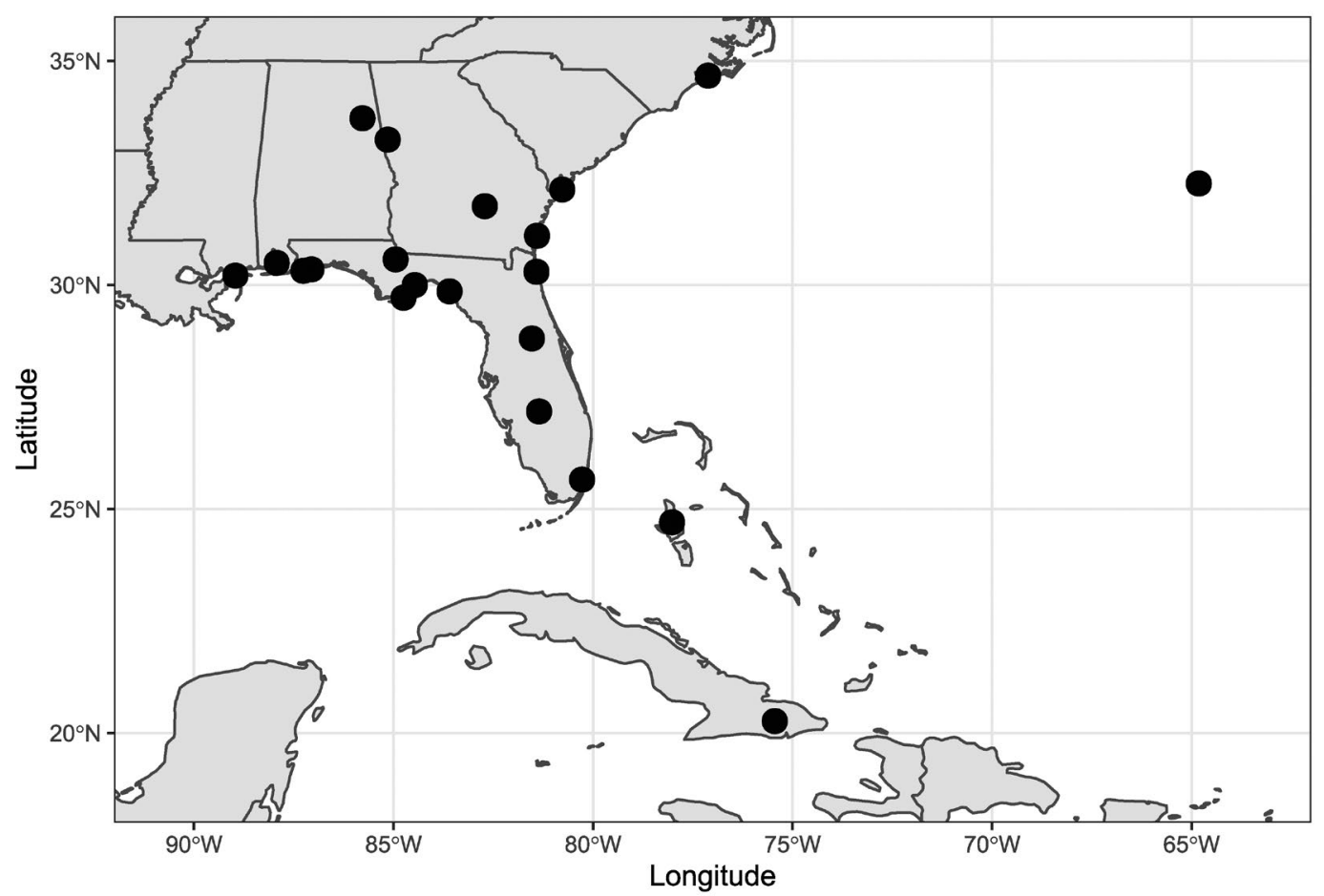

Figure 3. Known distribution of Chrysothrix bergeri (the eastern-most dot marks the Bermuda archipelago). 
of Laundon's (1981) synonyms for C. candelaris are Old World in origin. It is, therefore, highly unlikely that any of those synonyms represent previous names for $C$. bergeri, a New World species. If future monographers of Chrysothrix are able to demonstrate that one of those synonyms is conspecific with $C$. bergeri, then $C$. bergeri may itself be relegated to synonymy. Until that time, however, this common lichen needs a name, so that it can be included in regional species checklists and floras.

Another similar southeastern Chrysothrix species whose range overlaps that of $C$. bergeri is $C$. insulizans (Harris \& Ladd 2008). Although the two species cannot easily be separated on the basis of chemistry (C. insulizans produces calycin plus leprapinic acid), C. insulizans is usually quite different morphologically, its thalli consisting of separate, soralium-like patches. In addition, in areas where the two species co-occur, $C$. insulizans almost always grows on rocks. As mentioned in Harris and Ladd (2008), the corticolous specimens of C. insulizans - only three of which (Shchepanek 29A, CANL; Wetmore 65307, NY; and Harris 47176, NY) have been collected within the geographic range of $C$. bergeri - merit closer inspection, as they probably represent another distinct species (or, perhaps, multiple species).

Originally, I considered Bilimbia aurata - a yellow, leprose lichen described from the Bahamas (Riddle 1920) - as a potential, earlier name for C. bergeri. Bilimbia aurata, however, produces pinastric acid only, and has granules 20-50 $\mu \mathrm{m}$ (Britton 221, FH!, lectotype designated below), making it a synonym of C. xanthina (Harris $\&$ Ladd 2008). (NB: Britton's collector number is 221, not 2221 as erroneously reported by Harris and Ladd 2008, who examined the NY duplicate). Like the type collection, one of the other specimens (Thaxter 64, FH!: pinastric acid only, granules $32-52 \mu \mathrm{m}$; duplicate in NY) cited by Riddle (1920) in the protologue of B. aurata is also C. xanthina; another (Brace 5297, NY!) is C. bergeri. Another potential, earlier name for C. bergeri-Bilimbia stevensonii, described from Puerto Rico - was also investigated as part of the present study. Two authentic samples of B. stevensonii (Stevenson 5163, FH! - both isotypes) yielded pinastric acid only by TLC, and possess granules $20-50 \mu \mathrm{m}$, confirming Harris and Ladd's (2008) suspicion that $B$. stevensonii is, like B. aurata, also a synonym of $C$. xanthina.

In Bermuda, Chrysothrix bergeri is the only species of Chrysothrix present. The first modern Bermudian specimen of this species, collected in 2004 by Franz Berger on Casuarina equisetifolia (Berger 19580, DUKE), was the most luxuriant, well-developed material of this species so far examined. Initially, it was my first choice for the holotype. Unfortunately, it is sterile, so I was obligated to instead choose the only known fertile specimen (Hioram 5777, NY), which was collected from Cuba.

It should be noted here that leprapinic and pinastric acids are nearly impossible to tell apart on TLC plates using the standard solvents $\mathrm{A}, \mathrm{B}$ ', and $\mathrm{C}$, which prompted solicitation of a second opinion on the chemistry of Chrysothrix bergeri from Jack Elix. Upon learning of the easy separation of leprapinic and pinastric acids in
Solvent E from Jack, I subsequently re-ran all specimens of $C$. bergeri in solvent $\mathrm{E}$. The fact that Harris and Ladd (2008) did not run solvent E casts some doubt on their observations regarding Chrysothrix species identification in eastern and central North America. Their discernment of the species named here as $C$. bergeri, however, is not problematic since, according to a comparative table of the Chrysothrix species they treat (Table 1, p. 30, Harris \& Ladd 2008), no morphologically similar, lignicolous/ corticolous Chrysothrix species in the southeastern USA are also chemically similar - except for the three corticolous specimens of $C$. insulizans mentioned above. These three specimens (i.e. Shchepanek 29A, CANL; Wetmore 65307, NY; and Harris 47176, NY) need to be checked to ascertain if they are, in fact, $C$. bergeri.

In future studies of the genus Chrysothrix, it is highly recommended that solvent E (Elix \& Crook 1992) be used in addition to the standard three-solvent system for TLC of lichen secondary products. It is also recommended that workers continue to survey herbarium specimens of ' $C$. candelaris' from North America and the Caribbean with TLC, in the hopes of better understanding the geographic distributions of $C$. bergeri, C. xanthina and similar species.

\section{Specimens examined (Chrysothrix bergeri, chemotype 1 ).} Calycin (major) plus pinastric acid (major) and leprapinic acid (minor). BAHAMAS. Andros: Barton Creek, 18 Aug. - 10 Sept. 1908, Brace 5297 (orig. det. as Bilimbia aurata; NY). BERMUDA. Hamilton Parish: Walsingham Jungle Preserve, $32.26722^{\circ} \mathrm{N}, 64.81889^{\circ} \mathrm{W}, 20 \mathrm{~m}, 2$ Nov. 2007, LaGreca 2510 (BM); Southampton Parish: Along Railway Trail, 40 m, 15 Nov. 2004, "Berger 19580 (DUKE); (no specific locality), 13 Dec. 1915, Hervey s.n. (FH). UNITED STATES. Alabama. Baldwin Co.: Battles, 21 Nov. 1924, Evans 88 (FH). Florida. Duval Co.: Jacksonville Beach, E of San Pablo River, W of 17th St. N, 19 June 1975, Buck B160 (NY); Escambia Co.: Santa Rosa Island, University of West Florida Big Sabine Point Preserve, just W of Big Sabine Bay, just W of Pensacola Beach along Via de Luna Dr (CR399), $30.35058^{\circ} \mathrm{N}, 87.05757^{\circ} \mathrm{W}, \sim 6 \mathrm{~m}, 8$ Aug. 2017, Morse 26965, 26966 (DUKE, KANU); Liberty Co.: Torreya State Park, $\sim 1$ mile NW of Rock Bluff, along Weeping Bluff trail, 3 Jan. 1991, Ladd 14600 (hb. Ladd); Taylor Co.: Along CR361, $1.7 \mathrm{mi} \mathrm{N}$ of Keaton Beach, $29^{\circ} 52^{\prime} \mathrm{N}, 83^{\circ} 36^{\prime} \mathrm{W}, 3$ Dec. 1996, Buck 31154 (NY); Wakulla Co.: Ochlockonee River State Park, along NE shore of Ochlockonee River, $\sim 0.1$ miles south of Dead River, $30.001^{\circ} \mathrm{N}, 84.468^{\circ} \mathrm{W}, 29$ Dec. 1990, Ladd 14442 (hb. Ladd). Georgia. Glynn Co.: Jekyll Island State Park, 6 mi SE of Brunswick, in vicinity of North Picnic Ground, along the NE beach, $31^{\circ} 06^{\prime} \mathrm{N}, 81^{\circ} 24^{\prime} 15^{\prime \prime} \mathrm{W}, 0$ m, 24 Dec. 1969, Egan El-3869 (US). Mississippi. Harrison Co.: Ship Island, quarantine station, 30 Jan. 1954, Demaree 34637 (FH). North Carolina. Onslow Co.: Hammocks Beach State Park, NE end of Huggins Island, $34^{\circ} 40^{\prime} 23^{\prime \prime} \mathrm{N}, 77^{\circ} 06^{\prime} 55^{\prime \prime} \mathrm{W}, 1.5-3 \mathrm{~m}, 25$ Oct. 2013 , "Harris 59127 (NY). South Carolina. Beaufort Co.: town of Hilton Head Island, Forest Preserve at Sea Pines Plantation, 10 Apr. 2012, "Battaglia 2012-043 (CUP, NY).

Specimens examined (Chrysothrix bergeri, chemotype 2). Calycin only. BERMUDA. Smith's Parish: Spittal Pond, 5-10 m; 14 Nov. 2004, Berger 22365 (DUKE, hb. Berger). CUBA. Confianza Estate, 4 Mar. 1922, Hioram 5771 (fertile; NY!, holotype). UNITED STATES. Alabama. Calhoun Co.: Fort McClellan, 26 Jan. 1977, *Worthley L-633 (NY) (The 
granules of this specimen were considered too large by Harris and Ladd (2008) to be placed confidently, but my measurements place it within C. bergeri). Florida. Escambia Co.: Gulf Island National Seashore, Santa Rosa Island, Fort Pickens area, near ranger station, $30^{\circ} 19^{\prime} 06^{\prime \prime} \mathrm{N}, 87^{\circ} 15^{\prime} 36^{\prime \prime} \mathrm{W}, \sim 3 \mathrm{~m}$, 22 Nov. 2002, Guarisco 55 (KANU); Franklin Co.: St. George Island State Park, on E end of St. George Island, E of Apalachicola, $29.700^{\circ} \mathrm{N}, 84.798^{\circ} \mathrm{W}, 2$ Jan. 1991, Ladd 14579 (hb. Ladd); Lake Co.: Mt. Plymouth, 12 Aug. 1964, Moore 2113 (DUKE); Miami-Dade Co.: Montgomery Botanical Center, $25.65873^{\circ} \mathrm{N}, 80.275^{\circ} \mathrm{W}, 17 \mathrm{~m}, 25$ Aug. 2019 , LaGreca 2655 (DUKE). Georgia. Heard Co.: Camp Meeting Rock Preserve, off GA 34 SW of Franklin, $33^{\circ} 14^{\prime} 41^{\prime \prime} \mathrm{N}, 85^{\circ} 08^{\prime} 41^{\prime \prime} \mathrm{W}, \sim 250 \mathrm{~m}$, 1 Oct. 1999, Harris 43313 (NY); Jeff Davis Co.: $0.4 \mathrm{mi}$ E of Coffee Co. line on Georgia Hwy 107, $11 \mathrm{mi}$. NE of Broxton, $\sim 2 \mathrm{mi}$. S of Ocmulgee River, $31^{\circ} 45^{\prime} \mathrm{N}, 82^{\circ} 43^{\prime} \mathrm{W}, \sim 75 \mathrm{~m}, 5 \mathrm{Feb}$. 1995, Harris 36189 (NY).

In addition to the specimens cited above, one specimen (Harris 41773, NY), collected from a fencepost, possesses a chemistry similar to that of $C$. candelaris: calycin (major) and possibly pinastric acid (minor), plus many longwave-UV-fluorescent substances (probably from the bark), but no leprapinic acid. Its granules, however, are $31-43.5 \mu \mathrm{m}$ wide, which fits within the range of $C$. bergeri.

Specimens examined (Chrysothrix cf. bergeri). UNITED STATES. Florida. Highlands Co.: Archbold Biological Station, on old SR8, W boundary fire lane of SE Tract, $27^{\circ} 09^{\prime} \mathrm{N}$, $81^{\circ} 20^{\prime} \mathrm{W}, 26$ Mar. 1998, Harris 41773 (NY).

The chemistries of comparative material of $C$. candelaris, C. insulizans and C. xanthina (listed below) examined for this paper were mostly, but not entirely, determined by me using solvents A, B' and C. Those specimens cited below whose chemistry was determined by other workers are denoted with a cross $(\dagger)$, together with the name of the person (or persons) who performed the chemical analysis.

Specimens examined [Chrysothrix candelaris (L.) ].R. Laundon]. FINLAND. Åland, Ytternäs, 28 May 1957, (†R.C. Harris) Räsänen s.n. (DUKE). FRANCE. Midi-Pyrénées, HautesPyrénées, Pont d'Espagne, 13 June 1964, (†C.F. Culberson, R.C. Harris) Culberson 11811 (DUKE). SWEDEN. Kalmar, Öland, Böda parish, 1-1.5 km SE of Grankulla, 4 July 1962 (†J.R. Laundon - det. in BM duplicate) Santesson 14558 (DUKE). SWITZERLAND. (no specific locality), (no date), (†R.C. Harris) Schleicher 384 (DUKE).

Specimens examined (Chrysothrix insulizans R.C. Harris \& Ladd). UNITED STATES. Florida. Leon Co.: 6 mi NE of Tallahassee, along Highway 261, (no date), Moore 4585 (DUKE). North Carolina. Chatham Co.: near Chatham-Orange Co. line, $\sim 6$ mi SW of Chapel Hill, off Manns Chapel Road, 3 May 1961, (†R.C. Harris) Culberson 10422 (DUKE); Orange Co.: Duke Forest, New Hope Creek Division, 1962, Culberson 10842 (DUKE); Wilkes Co.: Stone Mountain State Park, SW slope of Stone Mountain, 11 Sept. 1972, (†R.C. Harris) Taggert 3 (DUKE).

Specimens examined [Chrysothrix xanthina (Vain.) Kalb]. ANGOLA. Distr. Golungo Alto., Dec. 1855, Welwitsch, Iter Angolense no. 447 (BM, lectotype). BAHAMAS. New Providence: Farrington Road, 24 Aug. 1904, Britton 221 (orig. det. as Bilimbia aurata Riddle; FH, lectotype designated here; NY, isolectotype). CHINA. Fujian Province: Xiamen, 5 Nov. 1998, Abbas 20010162 (FH). CUBA. Santiago de Cuba, Oriente, Arroyo de la Costa, 7 Nov. 1955, Diaz-Piferrer 105 (DUKE). MARTINIQUE. Le Marin, $3 \mathrm{~km}$ N of Les Anse d'Arlet, 22 Dec. 1969, Culberson 14698 (DUKE); Les-Trois-Îlets, 3 km E of
Trois Îlets, 22 Dec. 1969, Culberson 14718 (DUKE). PUERTO RICO. Rio Piedras, on back of fence post, 14 Apr. 1916, Stevenson 5163 p.min.p. and Stevenson 5163 p.max.p (both orig. det. as Bilimbia stevensonii Fink ex J. Hedrick; ! FH, both isotypes; $\mathrm{MICH}$, holotype). UNITED STATES. Florida. Lee Co.: vicinity of Fort Myers, 29 Feb. 1916, Standley 12993 (US); Liberty Co.: Appalachicola River, Alum bluffs, 3 Sept. 1954, Sharp s.n. (US); Palm Beach Co.: Palm Beach, (no date), Thaxter 64 (orig. det. as Bilimbia aurata Riddle; FH); Polk Co.: Tiger Creek Preserve, along road, 7 Jan. 1989, Wheeler s.n. (NY). Kentucky. Whitley Co.: Cumberland Falls, 28 July 1941, Allen 74 (NY, US). New York. Washington Co.: woods E of Tripoli schoolhouse, town line between Kingsbury and Fort Ann, 3 June 1906, Burnham s.n. (CUP). North Carolina. Hoke Co.: $8 \mathrm{mi}$ S of Raeford, Sept. 1958, Culberson 7598 (DUKE); Wake Co.: NE of the intersection of SR 2320 (Riley Hill Road) and SR 2329 (Lizard Lick Road), $4 \mathrm{mi} \mathrm{N}$ of Wendell and $4 \mathrm{mi} \mathrm{W}$ of Zebulon, 20 Oct. 2017, Goyette S23 (DUKE). TEXAS. Hunt Co.: Clinton, 8 Feb. 1925, Thurow s.n. (US).

\section{Acknowledgements}

I am grateful to Phillipe Clerc for teaching me the value of collections-based research early in my career. Jack Elix is warmly thanked for chemical verification of representative specimens. The author also thanks Doug Ladd (MO), James Lendemer (NY) and Caleb Morse (KANU) for loans of critical specimens. Don Pfister, Michaela Schmull, Genevieve Tocci and James Mitchell graciously hosted me while at herbarium FH, allowing me to take fragments of key specimens for TLC. Manuela dal Forno and Meghann Toner did the same for me at herbarium US. Hannah Merchant (FH) kindly sent me images of additional Farlow Chrysothrix specimens that I had examined and annotated in the past, but had forgotten to record in my notes. I am very grateful to Bryan Piatowski (DUKE) for generating the range map; and to Keith Babuszczak, Doug Goldman and Martin Kukwa for their helpful comments on the manuscript.

\section{References}

Aptroot, A., Sparrius, L., LaGreca, S. \& Bungartz, F. 2008. Angiactis, a new crustose lichen genus in the family Roccellaceae with species from Bermuda, the Galápagos Islands, and Tasmania. The Bryologist 111: 510-516.

Berger, F. \& Aptroot, A. 2008. Bactrospora flavopruinosa, a new lichen species from Bermuda. The Lichenologist 40: 543-547.

Berger, F. \& LaGreca, S. 2014. Contributions to the lichen flora of Bermuda - Part I. New records, new combinations, and interesting collections of lichenized ascomycetes. Evansia 31: 41-68.

Berger, F., LaGreca, S. \& Aptroot, A. 2016. Lithothelium bermudense sp. nov., a new saxicolous lichen from Bermuda. Mycotaxon 131: $527-533$.

Culberson, C. F. \& Ammann, K. 1979. Standardmethode zur Dünnschichtchromatographie von Flechtensubstanzen. Herzogia 5: 1-24.

Culberson, C. F. \& Johnson, A. 1982. Substitution of methyl tert-butyl ether for diethyl ether in the standardized thin-layer chromatographic method for lichen products. Journal of Chromatography 128: 253-259.

Elix, J. A. \& Crook, C. E. 1992. The joint occurrence of chloroxanthones in lichens, and a further thirteen new lichen xanthones. The Bryologist 95: 52-64.

Fletcher, A. \& W. O. Purvis. Chrysothrix. In: Smith C. W., Aptroot, A., B. J. Coppins B. J., O. L. Gilbert, P. W. James \& Wolseley, P. A. 2009 (eds). The Lichens of Great Britain and Ireland (2nd edition), pp. 208-309. British Lichen Society, London. 
Harris, R. C. \& Ladd, D. 2008. The lichen genus Chrysothrix in the Ozark ecoregion, including a preliminary treatment with for eastern and central North America. Opuscula Philolichenum 5: 29-42.

Kalb, K. 2001. New or otherwise interesting lichens. I. Bibliotheca Lichenologica 78: 141-167.

Kukwa M. \& Knudsen, K. 2011. Notes on the identity of Chrysothrix populations (Arthoniales, Ascomycota) containing pinastric acid from southern and central California. Mycotaxon 116: 407-411.

Laundon, J. R. 1981. The species of Chrysothrix. The Lichenologist 13: $101-121$.

Lendemer, J. C. \& Noell, N. 2018. Delmarva Lichens: An illustrated manual. Memoirs of the Torrey Botanical Society 28: 1-386.
Lendemer, J. C., Harris, R. C. \& Ruiz, A. M. 2016. A review of the lichens of the Dare Regional Biodiversity Hotspot in the Mid-Atlantic Coastal Plain of North Carolina, eastern North America. Castanea 81: 1-77.

Olszewska, S., Zwolicki, A., \& Kukwa, M. 2014. Chemistry and morphology of Chrysothrix candelaris in Poland, with notes on the taxonomy of C. xanthina. Mycotaxon 128: 165-172.

Riddle, L. W. 1920. Lichens. In: N. L. Britton \& C. F. Millspaugh (eds), The Bahama Flora, pp. 522-553. Published by the authors.

Tønsberg, T. 1992. The sorediate and isidiate, corticolous, crustose lichens in Norway. Sommerfeltia 14: 1-331. 